\title{
Attitudes of Mexican American Students Towards Learning English as a Second Language in a Structured Immersion Program
}

\author{
Diego URibe Martínez \\ El Camino College, CECC, Estados Unidos \\ José Gutiérrez Pérez and Daniel Madrid Fernández \\ Universidad de Granada
}

Received: 1 May 2012 / Accepted: 14 December 2012

ISSN: $1697-7467$

\begin{abstract}
This study involves the examination of the attitudes of a group of Mexican American students towards learning English as a second language in a structured immersion program. It also analyzes the extent to which these attitudes differ in relation to the variables of gender and performance in English. Participants were 110 students (girls, $\mathrm{n}=56$, boys, $\mathrm{n}=54$ ) in grades $8-12$ in the Compton Unified School District (California, USA). One noteworthy finding of this study is the appearance of a general factor that defines the homogeneous structure of the instruments used in the assessment of student attitudes toward second language learning. In addition, a further factor, which the authors have termed "pressure to learn English" was also identified. This factor is manifested in a high average correlation of all variables. It reveals the motivation to learn a second language in the context of vital necessity where learning English is a key element for the integration in a territory in which the use of Spanish is prohibited by law.
\end{abstract}

Keywords: Mexican American students, attitudes, structured English immersion, learning English as a second language.

Actitudes de los estudiantes méxico-americanos hacia el aprendizaje del inglés como segunda lengua en un programa estructurado de inmersión

RESUMEN: Este trabajo se propone explorar las actitudes de un grupo de estudiantes estadounidenses de origen mejicano hacia el aprendizaje del inglés como segunda lengua en un programa de estudios de inmersión. También analiza hasta qué punto estas actitudes difieren en función del sexo y la actuación del alumnado. Se ha empleado una muestra de 110 estudiantes (56 chicas y 54 chicos) de los grados 8 al 12 del Compton Unified School District, en California. Uno de los descubrimientos más notables de este estudio ha sido la aparición, en el análisis factorial, de un factor general que define la estructura homogénea de los instrumentos utilizados en la evaluación de las actitudes del estudiantado hacia el aprendizaje de la segunda lengua. También hemos encontrado otro factor clave que hemos denominado "presión social hacia el uso del inglés". Este factor se manifiesta con una alta correlación con todas las variables y revela que la motivación para el aprendizaje de una segunda lengua en un contexto de vital necesidad donde el aprendizaje del inglés es un factor clave para la integración social en un territorio 
en el que el uso del español en contextos formales está prohibido por ley.

Palabras clave: estudiantes méxico-americanos, actitudes, programas estructurados de inversión, aprendizaje de inglés como segunda lengua.

\section{INTRODUCTION}

Recent restrictions on the use of student's native languages appear to have affected the makeup of programs that may legally be employed in Californian classrooms. The system has changed from one in which the use of foreign languages was previously allowed to facilitate learning to one in which English is the only language used for daily instruction. The goal of the current study, therefore, is to see whether Spanish-speaking students in California have favorable or unfavorable attitudes towards learning English. A brief review of the recent history of the Hispanic community in California shows that, for most Hispanic educators, the real story begins with the Treaty of Guadalupe Hidalgo in 1848. This ended the war between the US and Mexico and the United States annexed the existing part of the southwest and started decades of continuing discrimination against Hispanics in general and Mexican Americans in particular. The most notable events have shifted from the exclusion of their cultural heritage to the mass segregation in schools (Valencia \& San Miguel, 1998).

The turning point of this story takes place in California in the early 1990s, with Propositions 187, 209 and especially 227, which limited the use of Spanish in schools and made the acquisition of English a matter of survival, leading the Latino community to an unprecedented educational crisis in their recent history. Proposition 227, arguably the most restrictive of all, was approved in 1998 in a direct attempt to dismantle bilingual education and the put obstacles to educational equality for Mexican-American students. Proposition 227, also known as English for the Children Initiative, was passed by the voters in the June 3, 1998 election by $56.4 \%$ in Los Angeles County and $61 \%$ throughout the State. This law established that of all public school children in California be instructed almost entirely in the English Language with the provision that parents/guardian could utilize waivers to relinquish this right if they so chose. This proposition is now formalized as part of the State of California's Education Code, Sections 300-340. This proposal represents one of the great ironies in the educational history of Mexican Americans: the adoption of this law against bilingualism occurred in 1998, that is, 150 years since the Treaty of Guadalupe Hidalgo, which agreed to protect civil and language rights -including Mexican Americans living in the new territory (Rendón, 1971). The sponsor of this proposal was the billionaire Ron Unz, the son of immigrants from Eastern Europe and who based his entire opinion of how he learned English without the help of bilingual education (Crawford, 2000). His initiative was only one of the many moves orchestrated in favor of English as the dominant and official language of the United States, and a clear attempt to equate speaking it well with being a good American (Lee, 2006).

\section{Literature REVIEW}

During the last decade, Californian schools have undergone a process of transformation of its student population, due in part to the increases in numbers of students from Spanish- 
speaking countries, especially Mexico. Currently, more than a million and a half of English learners, mostly Hispanics, attend public schools in California (Office of English Language Acquisition, 2005). Due to their limitations with English language, a series of programs have been designed to facilitate language learning in the shortest time. Of the programs chosen (and, in fact, the most widespread) is Structured English Immersion (SEI). Proposition 227, which severely restricted the use of students' native language, required by mandate that all Californian public schools adopt this program for teaching English learners. According to data from the Department of Education in California, some 755,000 students were enrolled in this program during the academic year 2004-2005 (McField, 2006).

From the outset, the definition of SEI has been confusing; it is not clear whether it is a language acquisition process, a program, a technique, a method, a curriculum, a presentation, or whether it refers to a class (McField, 2006). Unfortunately, the law does not provide much help for administrators and teachers, leaving it open to various types of modifications or methodological approaches to the teaching English learners (Mora, 2001). Originally, SEI included instruction in the native language of students, about 30 to 60 minutes per day. Over time this initial approach was changed to a program in which instruction is mainly in English, but the curriculum is designed for students who are learning the language (Unz \& Tuchman, 1997). Proposition 227, also known as the English for the Children initiative, required English learners to remain in SEI programs no longer than one year. Once students have a good command of English to survive in the class, they should be placed in the mainstream (Unz \& Tuchman, 1997). The philosophy of this program reveals a political agenda that promotes monolingualism in English and diverts resources away from bilingual programs (McField, 2006). Ironically, since the implementation of the initiative at national level the student outcomes have not changed, and as several studies point out, students in bilingual programs generally do better than students in programs instructed only or mainly English, like SEI (Francis, Lesaux \& August, 2006; Genesee, Lindolm-Leary, Saunders \& Christian, 2005; Slavin \& Cheung, 2005; Thomas \& Collier, 2004).

\subsection{Proposition 227 and its impact on teachers and students}

For many, the passing of Proposition 227 constituted a mixture of hope and anxiety, although very often attempts to change institutions and educational praxis do not yield the intended results (Stritikus \& Garcia, 2000). Like many top-down reforms, this initiative was not only imposed without consulting teachers, but had enormous challenges for this group: from legal responsibilities to implementation related issues. Although there was division of opinions about the importance of native language as a primary tool for adequate development of English learners (Sook Lee \& Oxelson, 2006), once this proposition was approved, they had no choice but to accept a model based on the instruction of students primarily in English. According to some educators (Alamillo \& Viramontes, 2000), this initiative had a very negative impact on both the cultural identity of students and their progress in school, because they believed that teachers' recognition of the importance of the native language in the life of students was a crucial process for their academic development. Educators have also proposed that recognition should be explicit and visible in the agenda of teachers (Sook 
Lee \& Oxelson, 2006). All this, coupled with other factors such as the institutionalization of national examinations, penalties for those teachers with negative academic outcomes or the lack of leadership on education policy, has exerted a great pressure on teachers and administrators. Many well-meaning educators are even recommending that parents use only English at home with their children, based mainly on past myths that associated bilingual education with confusion and delay (Wong-Fillmore, 2000) and properly exploited by proponents of the proposition and the media (Ramos, 2005). The pressure that Proposition 227 exerted on teachers and the education system in general seems to be having a negative effect also on learners (Ramos, 2005). It seems that students are losing their native languages at a rapid pace (Wong Fillmore, 1991, 2000) and, it is even affecting their motivational levels to learn English (Eleni, 2001). No wonder, then, before this general atmosphere was created, that although parents, students, and teachers generally appreciated the use of mother tongue in daily instruction, all of them prefered English for daily instruction (Lee, 2006; Ramos, 2001). In recent years there have been several studies on the opinions, attitudes and perceptions of parents (Allen, 2002; Lee 1999, 2006; Ramos, 2007), students (Lee, 2006; Lopez \& Tashakkori, 2006) and teachers (Flores, 2001; Karabenick \& Noda, 2004; Nevarez, Arias \& Stafford, 2005; Ramos, 2001, 2005; Sook Lee \& Oxelson, 2006) on bilingual education. The aim of this paper is to explore the attitudes of Mexican-American students toward learning English as a second language (L2) in a Structured Immersion Program (see also Uribe, 2001 and Uribe, Gutiérrez \& Madrid, 2008). This work represents an effort to improve understanding of the experiences of language minority children following the passage of the initiative English for the Children.

\section{Method}

\subsection{Participants}

The sample for this study consisted of 110 participants (girls, $n=56$, boys, $n=54$ ), randomly selected, and enrolled in grades 8 to 12 in a public school in the Compton Unified School District, South of Los Angeles. In this district, students with an English proficiency range from beginner to intermediate (California English Language Development Test [CELDT] levels 1, 2 and 3) are taken out from their classrooms for a period of between 30 and 50 minutes a day to receive English Language Development (ELD). All the study participants have participated in this program since they enrolled at the school for the first time and can be considered prototypes of the many students in ELD programs who attend suburban schools in California. The rest follows the English mainstream program. 
Table 1. Features of the Structured English Immersion program.

\begin{tabular}{lllllll}
\hline Source & $\begin{array}{l}\text { Description of a } \\
\text { Structured Immersion } \\
\text { Program (SEI) }\end{array}$ & $\begin{array}{l}\text { Teacher } \\
\text { uses L1 }\end{array}$ & $\begin{array}{l}\text { Student } \\
\text { uses L1 }\end{array}$ & $\begin{array}{l}\text { L1 } \\
\text { Instructional } \\
\text { Time }\end{array}$ & Level & Time \\
\hline Compton & An English acquisition & L1 is used & Yes & Up to 5\% ... & CELD & One \\
Unified & process where & to & & if the teacher & T & year \\
School & instruction is & motivate, & & is bilingual & $1 / 2 / 3$. & or \\
District & overwhelmingly in & clarify, & & & & more \\
& English. Only the & support & & & with a \\
& curriculum and & and & & & & waiver \\
& presentation are & explain & & & & \\
& designed for students & & & & & \\
& who are learning English & & & & & \\
& (English Learners & & & & & \\
& Master Plan, 2003) & & & & & \\
\hline
\end{tabular}

According to latest statistics, the school where the study was conducted has a population of 2,657 students, of whom 1,083, 40.3\% are English learners. $92.9 \%$ receive free lunch and breakfast and $98.9 \%$ are in compensatory education. Approximately $77.5 \%$ of students are Hispanic and 22.5\% African American. As for teachers, around 5\% are of Asian origin, $12 \%$ Filipino, 22.8\% Hispanic, 44.6\% African American and 12.2\% Caucasian. The percentage of teachers with full credentials is $75.8 \%$; the rest have emergency credentials (California Department of Education, 2006-2007). The percentage of students performing at the proficient level in the California Standardized Test (CST) in language was below 5\%. All participants in our study are of Mexican descent and born in the United States. Their families filled out the school Home Language Survey and indicated that in kindergarten their first language and most common language to communicate at home is Spanish. However, 30\% of students $(\mathrm{n}=34)$ preferred to use the questionnaire in English. The information was gathered by the researcher in December 2006 from ELD classes.

Table 2. Characteristics of the sample.

\begin{tabular}{lcc}
\hline & $n$ & $\%$ \\
\hline GRADE & & \\
\hline 8 & 34 & $30.9 \%$ \\
9 & 41 & $37.3 \%$ \\
10 & 16 & $14.5 \%$ \\
11 & 10 & $9.1 \%$ \\
12 & 9 & $8.2 \%$ \\
\hline CELDT Level & & \\
\hline 1 & 7 & $6.4 \%$ \\
2 & 28 & $25.5 \%$ \\
3 & 75 & $68.2 \%$ \\
\hline SEX & & \\
\hline Boys & 56 & $50.9 \%$ \\
Girls & 54 & $49.1 \%$ \\
\hline PERFORMANCE & & \\
\hline A & 9 & $8.2 \%$ \\
B & 30 & $27.3 \%$ \\
C & 54 & $49.1 \%$ \\
D & 9 & $8.2 \%$ \\
F & 5 & $4.5 \%$ \\
\hline
\end{tabular}




\subsection{Instruments}

A questionnaire with four subscales was used to measure student attitudes towards learning English as a L2 in a structured immersion program. The questionnaire was specifically designed for the study and was based mainly on models implemented by Gardner (1985), Jakobobitz (1970) and Madrid (1999). The questionnaire was offered in Spanish and English and was used satisfactorily in a pilot study in the months leading up to the study to check the validity and reliability of the instrument.

Information gathered during this early stage served to eliminate language that seemed difficult, to modify and suppress several statements and a fifth subscale. Explanations about the meaning of six words were givin before administering the questionnaire. The final questionnaire contained 71 statements divided into four subscales:

- attitudes towards the ELD teacher (ACTITEACHER),

- attitudes towards ELD textbooks (ACTIBOOKS),

- attitudes towards ELD tasks (ACTIWORK) and

- attitudes towards the ELD class (ACTICLASS)

- as well as 10 personal questions (see also Madrid and Pérez Cañado, 2000; Uribe, 2001).

Table 3. Questionnaire characteristics.

\begin{tabular}{|c|c|c|}
\hline Questionnaire & $\begin{array}{l}N^{o} \text { items/ } \\
\text { Scale } \\
\text { Reliability }\end{array}$ & Objectives \\
\hline $\begin{array}{l}1 \text { Attitudes towards the } \\
\text { ELD teacher } \\
\text { (ATTITEACHER) }\end{array}$ & $\begin{array}{l}17 \text { items } \\
\alpha=0.83\end{array}$ & $\begin{array}{l}\text { This questionnaire measured students' attitudes } \\
\text { towards the teacher's performance in the classroom, } \\
\text { treatment of students and class behavior. }\end{array}$ \\
\hline $\begin{array}{l}2 \text { Attitudes towards the } \\
\text { ELD textbooks } \\
\text { (ATTIBOOKS) }\end{array}$ & $\begin{array}{l}16 \text { items } \\
\alpha=0.85\end{array}$ & $\begin{array}{l}\text { This questionnaire measured students' attitudes } \\
\text { towards the school materials with special emphasis } \\
\text { on the textbook and class exercises: it also addressed } \\
\text { linguistic components, communication skills, use of } \\
\text { tables and diagrams. }\end{array}$ \\
\hline $\begin{array}{l}3 \text { Attitudes towards } \\
\text { ELD tasks } \\
\text { (ATTIWORK) }\end{array}$ & $\begin{array}{l}19 \text { items } \\
\alpha=0.85\end{array}$ & $\begin{array}{l}\text { This questionnaire measured students' attitudes } \\
\text { towards homework and class exercises: oral and } \\
\text { written activities communication drills, games, } \\
\text { grammar, culture, etc.. }\end{array}$ \\
\hline $\begin{array}{l}4 \text { Attitudes towards the } \\
\text { ELD class } \\
\text { (ATTICLASS) }\end{array}$ & $\begin{array}{l}19 \text { items } \\
\alpha=0.88\end{array}$ & $\begin{array}{l}\text { This questionnaire measured the students' attitudes } \\
\text { towards the English classroom: contents, activities, } \\
\text { methods, assessment, etc.. }\end{array}$ \\
\hline
\end{tabular}

Note $:$ ELD = English Language Development.

Reliability values were obtained for the sample by calculating the Cronbach alpha. As shown in Table 3, the overall reliability values obtained for this sample, and a set of 71 statements, are considerably high $(\alpha=0.94)$; this means that we can have a fair level of confidence in the results obtained with this set of instrument, since the number of statements is high and they maintain a strong internal consistency in the aspects measured partly on the 
four subscales. The global survey showed high internal consistency for the measurement of attitudes resulting in a general factor in which all variables are highly correlated.

\subsection{Procedures}

The office of the superintendent of the Unified School District Compton was contacted personally and, once permission was granted to conduct the study, 150 students were randomly selected from a school. The final sample was 110 since 40 participants were excluded for not completing more than half of the questionnaire. Teachers were accompanied by the investigator when distributing the questionnaire to students during the ELD block. Instructions in both English and Spanish were given prior to the administration of the questionnaires. Throughout the entire session support was provided to students regarding issues related to the completion of the questionnaire. Time spent to respond to the 71 statements $(1=$ very negative to $5=$ very positive $)$ of the four subscales was about an hour.

\subsection{Data analysis}

SPSS 18.0 was used for the analysis of data obtained from the four attitudinal subscales. The descriptive statistical effect size was used to examine the contrast between the mean values of the four subscales. An exploratory factor analysis was conducted as a technique to reduce data and to identify and validate the construct being measured with this set of items. Analysis of variance (ANOVA) was also used to see possible differences in students' responses based on the independent variables (gender and performance in English).

\subsubsection{Results of the four subscales}

We found the average values of the sample by the students of Mexican-American sample in each of the assessment questionnaires. In general, the attitude of students is around to 4, with an overall average of 3.9 (result of the total sum of the values obtained in the four subscales used). Overall, this value represents comes very close to "positive" to the four scales. A specific analysis of the partial means of each of the scales again confirms the previous observation, with values very close to the value 4 and even one of the scales that reached this value: ATTICLASS $(\mathrm{M}=3.96)$, ATTITEACHER $(\mathrm{M}=4.04)$, ATTITEXTS $(\mathrm{M}=3.87)$ and ATTIWORK $(\mathrm{M}=3.86)$. These values show that on average, the Mexican American students had positive attitudes learning English. The contrast between the mean values of the four scales gave us no great differences between them, based on the calculation of descriptive statistical effect sizes. This makes us understand that the perception of the different factors is homogeneous and, in general, none of them particularly stands out above the rest.

Levene's test for estimating the homogeneity of variance with the value of alpha at .05 , showed that the assumption of homogeneity of variance was met by the four subscales. For the questionnaire (ATTITEACHER $p=.093, p=.370$ ATTICLASS; ATTITEXTS $p=.445$, and $p=.880$ ATTIWORK) was also verified the assumption of normality of data distribution. It was examined whether the distribution was consistent with the normal curve, using as evidence of normality the Kolgmorov-Smirnoff test. 
Except the ATTICLASS scale $(\mathrm{p}=.005)$, the remaining subscales successfully met the assumption of normality.

ANOVA was conducted to examine changes in student attitudes by independent variable. As shown in Table 4, there were significant differences in gender. Girls showed more positive attitudes than boys towards class tasks $\mathrm{F}(4,110)=4.737, \mathrm{p}=0.032$. Moreover, attitudes towards the class and the textbooks' results also approached the level of significance.

Table 4. Results of the 4 subscales per independent variable.

\begin{tabular}{lllllll}
\hline & \multicolumn{2}{c}{ Gender } & \multicolumn{3}{c}{ Test Statistic } & \multicolumn{2}{c}{ Performance/GPA } \\
Subscale & Male & Female & $F$ & Sig. & $F$ & Sig. \\
\hline ACTICLAS & 3.8801 & 4.0432 & 3.647 & .059 & 2.215 & .091 \\
ACTIPROF & 4.0131 & 4.0609 & .339 & .561 & 5.429 & $.002^{* *}$ \\
ACTITEXT & 3.7917 & 3.9397 & 2.928 & .090 & 3.722 & $.014^{* *}$ \\
ACTIWORK & 3.7602 & 3.9568 & 4.737 & $.032^{* *}$ & 1.459 & .230 \\
\hline
\end{tabular}

Significant differences were also found in relation to the GPA variable. Top students showed more favorable attitudes towards the teacher, $F(4,110)=5.429, p=0.002$. and textbooks, $\mathrm{F}(4,110)=3.722, \mathrm{p}=0.014$, but no statistically significant differences were found by income in attitudes toward the class $F(4,110)=0.091$ and class assignments, $F$ $(4,110)=0.230$.

The 71 statements that made up the four subscales were subjected to an exploratory factor analysis. A main factor was found in which all variables saturated with highly significant weights: Attitudes toward learning English as a second language. This reinforces the value of the instrument as a tool for quality and high internal consistency for the assessment of attitudes towards English as L2.

Table 5 shows the factor weights of each variable in the main factor and the communalities of each variable, where there are very high values of communality for the 71 items. For this reason, all the questions in the questionnaire are well represented and its consideration is relevant in the study.

Table 5. Factorial loadings/weights in the main factor and communality.

\begin{tabular}{rccccc}
\hline ITEMS & $\begin{array}{c}\text { Factorial weight } \\
\text { in the Main } \\
\text { Factor }\end{array}$ & Communality & ITEMS & $\begin{array}{c}\text { Factorial } \\
\text { weight in the } \\
\text { Main Factor }\end{array}$ & Communality \\
\hline 1. & .557 & .684 & 37. & .551 &, 825 \\
2. & .403 & .733 & 38. & .594 &, 772 \\
3. & .548 & .812 & 39. & .630 &, 701 \\
4. & .608 & .809 & 40. & .474 &, 774 \\
5. & .608 & .704 & 41. & .492 &, 757 \\
6. & .493 & .731 & 42. & .334 &, 810 \\
7. & .604 & .777 & 43. & .531 &, 809 \\
8. & .600 & .764 & 44. & .626 &, 832 \\
9. & .648 & .769 & 45. & .688 &, 797
\end{tabular}


Table 5. Factorial loadings/weights in the main factor and communality (Cont).

\begin{tabular}{cccccc}
\hline ITEMS & $\begin{array}{c}\text { Factorial weight } \\
\text { in the Main } \\
\text { Factor }\end{array}$ & Communality & & $\begin{array}{c}\text { Factorial } \\
\text { weight in the } \\
\text { Main Factor }\end{array}$ & Communality \\
\hline 10. & .423 & .764 & 46. & .659 &, 812 \\
11. & .432 & .819 & 47. & .600 &, 767 \\
12. & .484 & .812 & 48. & .518 &, 857 \\
13. & .348 & .838 & 49. & .599 &, 858 \\
14. & .551 & .802 & 50. & .461 &, 759 \\
15. & .549 & .762 & 51. & .621 &, 756 \\
16. & .519 & .734 & 52. & .577 &, 786 \\
17. & .447 & .762 & 53. & .479 &, 751 \\
18. & .550 & .772 & 54. & .439 &, 834 \\
19. & .380 & .782 & 55. & .486 &, 795 \\
20. & .677 & .859 & 56. & .420 &, 782 \\
21. & .579 & .797 & 57. & .498 &, 738 \\
22. & .445 & .806 & 58. & .661 &, 868 \\
23. & .535 & .804 & 59. & .599 &, 741 \\
24. & .483 & .754 & 60. & .673 &, 820 \\
25. & .577 & .768 & 61. & .540 &, 845 \\
26. & .479 & .811 & 62. & .444 &, 787 \\
27. & .406 & .849 & 63. & .578 &, 785 \\
28. & .570 & .790 & 64. & .611 &, 747 \\
29. & .465 & .800 & 65. & .720 &, 785 \\
30. & .461 & .769 & 66. & .573 &, 788 \\
31. & .432 & .798 & 67. & .580 &, 785 \\
32. & .507 & .739 & 68. & .566 &, 801 \\
33. & .582 & .710 & 69. & .608 &, 696 \\
34. & .613 & .752 & 70. & .604 &, 808 \\
35. & .602 & .743 & 71. & .632 &, 826 \\
36. & .507 & .789 & & & \\
\hline
\end{tabular}

The following tables show the different factor solutions of the 4 subscales from a Varimax rotation analysis. Factor loadings of the variables associated with each factor are included, as well as the mean and standard deviation of each variable and the percentage of variance explained by each of the factors in the 4 subscales.

Table 6 shows the 5 factors and factor loadings for items 1 to 17, which comprise the ATTITEACHER subscale. Items 1, 3, 4, 5, 7 and 9 loaded onto Factor 1, labeled "teaching methodology" ; items 3, 6, 8, 10, 13, 15 and 16 loaded onto factor 2, labeled "English language use pressure, motivation, discipline and evaluation"; items 12, 14 and 17 loaded onto factor 3, was labeled "grouping pattern with audio-visuals and games" ; items 8,9 , 11, 14 and 16 loaded onto Factor 4, labeled" and class methodology"; items 2, 13 and 16 loaded onto factor 5, labeled "teacher behavior towards students". All items have obtained an average rating above 3.51. The two items with a higher evaluation are treatment of students (4.35) and teacher behavior to the needs and interests of students (4.32). Items with lower ratings are audio visuals/media use (3.51) and the use of games and recreational activities $(3,63)$. The variance explained by the 5 factors for the ATTITEACHER subscale is $58 \%$, very acceptable. Factor 1 explained $26.6 \%$ of the variance and the remaining 4 factors explained $31.4 \%$ of the variance. 
Table 6. Rotated Factorial Solution for the ATTITEACHER subscale

\begin{tabular}{|c|c|c|c|c|c|c|c|}
\hline \multirow[t]{2}{*}{ ITEM } & \multirow[t]{2}{*}{ Mean } & \multirow[t]{2}{*}{$S D$} & \multicolumn{5}{|c|}{ Factors } \\
\hline & & & 1 & 2 & 3 & 4 & 5 \\
\hline $\begin{array}{l}\text { 1. Way of teaching L2 subject } \\
\text { matter }\end{array}$ & 4,10 & ,76 & ,770 & & & & \\
\hline $\begin{array}{l}\text { 2. Behavior and attitude } \\
\text { towards students }\end{array}$ & 4,32 &, 73 & & & & &, 714 \\
\hline 3. Class explanations & 4,28 &, 71 & ,662 & & & & \\
\hline 4. Class preparation & 4,11 &, 83 & ,708 & & & & \\
\hline $\begin{array}{l}\text { 5. Favor students participation } \\
\text { in class }\end{array}$ & 3,89 & ,94 &, 505 & & & & \\
\hline 6. Motivation to teach & 4,35 & ,68 & & ,724 & & & \\
\hline 7. Class materials & 3,84 &, 86 & ,641 & & & & \\
\hline 8. Motivates students & 4,15 &, 80 & &, 577 & & ,375 & \\
\hline 9. Class methodology & 4,02 & ,90 &, 468 & & &, 597 & \\
\hline 10. Assessment practices & 3,83 &, 87 & & ,346 & & & \\
\hline $\begin{array}{l}\text { 11. Oral and griten work } \\
\text { balance }\end{array}$ & 4,03 & ,89 & & & & ,768 & \\
\hline 12. Audio visuals & 3,51 &, 75 & & & ,760 & & \\
\hline 13. Way students are treated & 4,35 & 67 & & & & &, 771 \\
\hline $\begin{array}{l}\text { 14. Variety of class work: pairs, } \\
\text { group, individual }\end{array}$ & 4,00 &, 81 & & &, 595 & & \\
\hline 15. Discipline & 4,24 & ,91 & & ,495 & & & \\
\hline $\begin{array}{l}\text { 16. Sociolingüístic and cultural } \\
\text { emphasis }\end{array}$ & 4,01 &, 88 & & & & ,591 & \\
\hline $\begin{array}{l}\text { 17. Games and free time } \\
\text { activities }\end{array}$ & 3,63 & ,98 & & &, 718 & & \\
\hline \multicolumn{3}{|l|}{ Eigenvalue } & $-4,7$ & 1,62 & 1,26 & 1,21 & 1,10 \\
\hline \multirow{2}{*}{\multicolumn{3}{|c|}{$\begin{array}{l}\% \text { Total of Variance Explained } \\
\text { Cumulative \% Total of Variance Explained }\end{array}$}} & 27,6 & 9,5 & 7,4 & 7,1 & 6,5 \\
\hline & & & 27,6 & 37,1 & 44,5 & 51,6 & 58 \\
\hline
\end{tabular}

Table 7 shows the 6 factors and factor loadings for items 18 to 36, which comprise the ATTICLASS subscale. Factor 1, "class content, class activities and assessment" carries items 18, 23, 26, 30, 34 and 36; Factor 2, called "class methods" carries items 20, 21, 22, 23 and 28; factor 3, called "discipline" carries the items 29,32, 33 and 34; factor 4, known as "group work" carries items 26, 27 and 31; factor 5, called "demand and class rate" carries items 26, 25, 36; factor 6, called "materials, activities and classroom atmosphere" carries items 19, 24 and 33. All items have obtained an average rating above 3.53. The two items with a higher evaluation are teacher explanations (4.11) and teacher corrections (4.11). Items with lower ratings are the use of songs and games (3.53) and activities in pairs (3.82). The variance explained by 6 factors in the ATTICLASS subscale is $63 \%$, very acceptable. The factor explains the $27,5 \%$ of the variance and the remaining 5 factors explain $35.5 \%$ of the variance. 
Table 7. Rotated Factorial Solution for the ATTICLASS subscale.

\begin{tabular}{|c|c|c|c|c|c|c|c|c|}
\hline \multirow[t]{2}{*}{ ITEM } & \multirow[t]{2}{*}{ Mean } & \multirow[t]{2}{*}{$S D$} & \multicolumn{6}{|c|}{ Rotation Factorial Solution of the ATTICLASS subscale } \\
\hline & & & 1 & 2 & 3 & 4 & 5 & 6 \\
\hline 18. L2 contents & 4,09 & 79 & 705 & & & & & \\
\hline 19. Class materials & 4,02 &, 70 & & & & & & ,432 \\
\hline $\begin{array}{l}\text { 20. Teacher } \\
\text { explanations }\end{array}$ & 4,11 & ,90 & &, 517 & & & & \\
\hline $\begin{array}{l}\text { 21. Teacher } \\
\text { methodology }\end{array}$ & 4,05 &, 80 & & ,599 & & & & \\
\hline $\begin{array}{l}\text { 22. Students class } \\
\text { participation rate }\end{array}$ & 4,05 &, 90 & & ,738 & & & & \\
\hline 23. Written activities & 3,98 & 88 &, 528 &, 563 & & & & \\
\hline 24. Oral activities & 3,91 &, 81 & & & & & & ,777 \\
\hline $\begin{array}{l}\text { 25. Individual } \\
\text { activities }\end{array}$ & 4,20 &, 80 & & & & & ,692 & \\
\hline 26. Team activities & 3,86 & ,94 & ,485 & & & ,591 & & \\
\hline $\begin{array}{l}\text { 27. Activities in } \\
\text { pairs }\end{array}$ & 3,82 & ,96 & & & &, 861 & & \\
\hline $\begin{array}{l}\text { 28. Teacher } \\
\text { corrections }\end{array}$ & 4,11 & ,93 & & 649 & & & & \\
\hline $\begin{array}{l}\text { 29. Discipline in } \\
\text { class }\end{array}$ & 3,96 & ,93 & & & ,742 & & & \\
\hline $\begin{array}{l}\text { 30. Teacher } \\
\text { assessment }\end{array}$ & 3,90 & 86 &, 542 & & & & & \\
\hline $\begin{array}{l}\text { 31. Songs and } \\
\text { games }\end{array}$ & 3,53 & ,94 & & & & ,708 & & \\
\hline 32. Howework & 3,99 &, 75 & & & ,733 & & & \\
\hline $\begin{array}{l}\text { 33. Class } \\
\text { atmosphere }\end{array}$ & 3,92 & 89 & & & ,435 & & &, 580 \\
\hline $\begin{array}{l}\text { 34. Teacher } \\
\text { pronunciation }\end{array}$ & 4,06 & ,90 & ,421 & &, 578 & & & \\
\hline 35. Class pacing & 3,91 & ,98 & & & & & 635 & \\
\hline 36. Classmates & 3,84 &, 87 &, 523 & & & & ,591 & \\
\hline Eigenvalue & & & 5,22 & 1,76 & 1,48 & 1,27 & 1,16 & 1,08 \\
\hline$\%$ Total of Variance & plained & & 27,5 & 9,24 & 7,83 & 6,68 & 6,12 & 5,67 \\
\hline $\begin{array}{l}\text { Cumulative \% Total } \\
\text { Explained }\end{array}$ & Variance & & 27,5 & 36,7 & 44,5 & 51,2 & 57,3 & 63 \\
\hline
\end{tabular}

Table 8 shows the 5 factors that bind items 37 to 52 together in the ATTITEXT subscale. Factor 1, known as "content dissemination and skills developed" carries items 38, 43, 44, 45, 46 and 47; factor 2, called "activities format" carries items 37, 41, 45, 46, 49 and 51; factor 3, called "treatment of reading-writing, interdisciplinary and acculturation" carries the items 39, 40, 46, 47, 47 and 52; factor 4, entitled "treatment of vocabulary" loaded items 39 and 50; factor 5, called "songs, games and reading" carries items 42 and 48 . All items have obtained an average rating above 3.5. The two items with a higher evaluation are reading activities (4.05) and the connection with other areas of curriculum (4.00). Items with lower ratings are pictures and diagrams (3.65) and using songs and games (3.58). The variance explained by the 5 factors in the ATTITEXT subscale is $63 \%$, very acceptable. Factor 1 explains $32 \%$ of the variance and the remaining 4 factors explain the $31 \%$ of the variance. 
Table 8. Rotation Factorial Solution of the ATTITEXT subscale

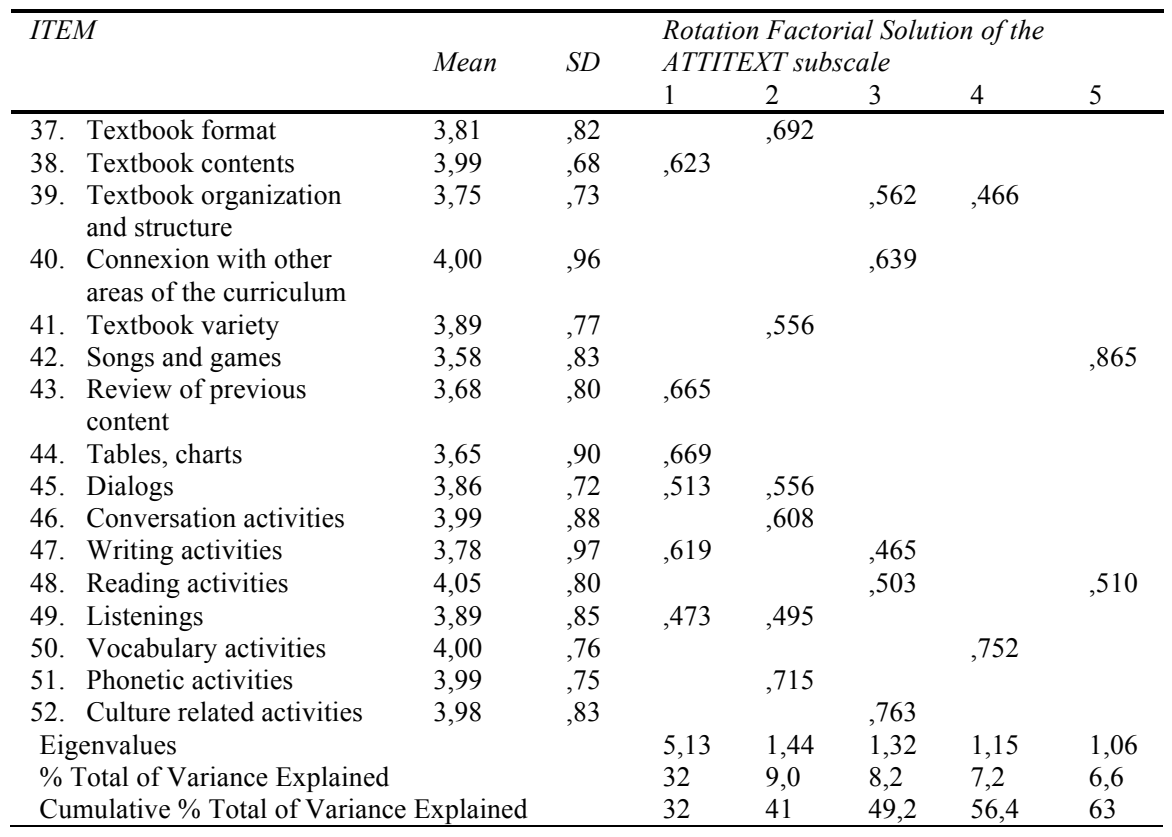

Table 9 shows the 5 factors that bind items 53 to 71 together in the ATTIWORK scale. Factor 1, known as "typically academic tasks" carries items 60, 62, 63, 66, 70 and 71; factor 2, called "after school tasks to motivate students" carries items 53, 54 and 55; factor 3, called "speaking activities" carries items 55, 56, 57, 59 and 67; factor 4, known as "projects, team activities and inculturation" carries items 58, 68 and 69; factor 5, called "grammar and pronunciation activities" carries items 61, 63 and 65. All items have obtained an average rating above 3.39. The two items with a higher evaluation are vocabulary activities (4.10) and individual activities (4.11). Items with lower ratings are listenings (3.39) and using games and songs (3.44). The total of variance explained by the 5 factors in the ATTIWORK subscale is $63 \%$, very acceptable. Factor 1 explains $32 \%$ of the variance and the remaining 4 explain $31 \%$ of the variance. 
Table 9. Rotation Factorial Solution of the ATTIWORK subscale.

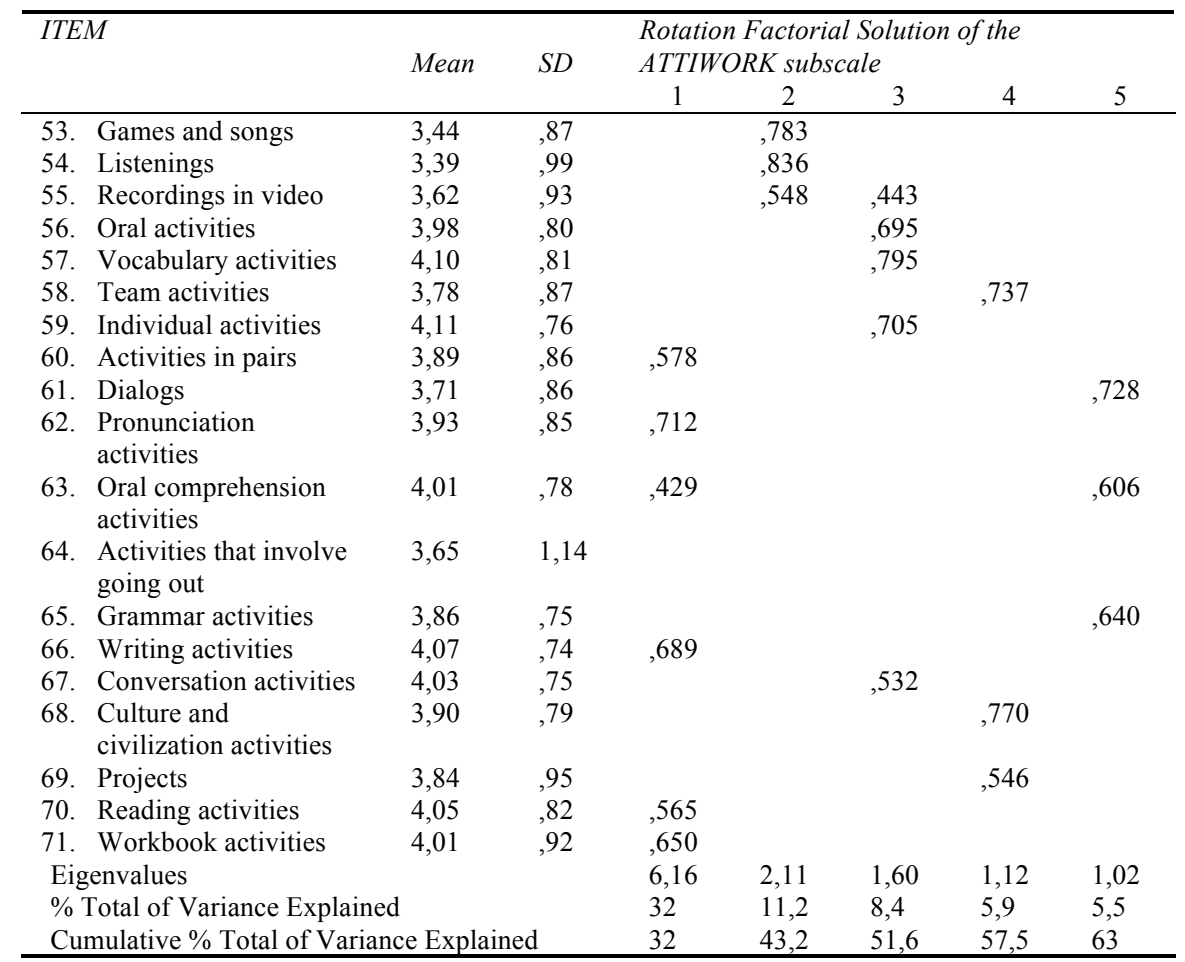

\section{Discussion}

The results of this study indicate that the attitudes of Mexican American students toward learning English as a L2 within a structured immersion program were generally positive. Students showed good disposition toward the L2 learning in its various facets. Their perceptions are very similar to all items of the four subscales, indicating that the group is very homogeneous and shared the same vision to the attitudinal construct studied. This sample of students seemed to feel that studying English is a need in their lives; however, more positive attitudes were expected. Maybe their personal motivations and the external environment make English an important element in their lives, and thus, a priority.

The attitudes of this sample of Mexican American students towards the classroom, the teacher, the textbook and class assignments have been generally very similar. It should be noted, though, that attitudes towards the teacher have been slightly more positive than towards other components. This is hardly surprising, since, the teacher plays an important role in adapting the elements of any reform (Stritikus \& Garcia, 2000). The message that learning English is an inescapable fact possibly has permeated the attitudes of students. Significant differences have also been found in gender and performance/GPA variables. Girls showed 
more positive attitudes than boys towards class assignments. Students with better grades, showed more favorable attitudes toward the teacher than students with lower grades.

It is possible that steady contact with second language speakers and the need to use English in their social circles of daily communication, outside the family, has encouraged the development of positive attitudes toward learning English. This idea seems to be consistent with the Contact Hypothesis and the numerous investigations in the field of social psychology since the 1950s (Allport, 1945). However, for a positive contact, there needs to be other conditions present, such as equality between groups, common goals, cooperation among groups, state support and potential to develop a friendship (Pettigrew, 2006). If this top-bottom reform has taught something, it is the disparity of opinion between those who usually developed educational policy that culminated with the passage of Proposition 227, and teachers, parents and students affected by this change. Moreover, no matter how laws promise to protect segregative practices and unequal treatment, inequalities persist. Often laws are not applied with a genuine commitment to achieving equality (Benavides, 2004) and unequal and coercive power relations with the majority group (Cummins, 2000) have led many students to despair and despondency (Ramos, 2007). In addition, the message that the federal government has launched with the initiative No Child Left Behind has been loud and clear: English is the only language of instruction. The students' mother tongues are not welcome in schools.

The factor analysis seems to corroborate previous research in the field that found closely ties between specific factors in different types of motivation and attitude developed in the classic works of Gardner (1985). In our study we found a main factor, which we have called "attitudes towards learning English". This is linked to a set of specific factors related to attitudes towards the teacher, methods employed, classes, materials used and the proposed tasks. The presence of this factor seems to indicate that this sample of students clearly perceived, possibly through the teachers, the message that learning English has become a matter of utmost importance. Proposition 227, also known as English for the Children, was going in this direction: to emphasize the need for immigrants to learn English. However, this initiative has resulted in denial of the culture and native languages of many newcomers. In this regard, the role of the teacher as a conduit of attitudes is important. So when teachers suggest that only learning English is important, students may infer that their native language and culture are irrelevant (Sook Lee \& Oxelson, 2006; Echevarria, Powers \& Short, 2006).). In the end, this may become a barrier to academic achievement (Ball \& Lardner, 1997) and affect student self-esteem (Wong Fillmore, 2000).

Pressure to use the English language could conceivably have positive nor negative affects on performance in the class. Further studies will have to determine if perceptions about pressure to use English are related to academic performance and motivational levels. That is, if the pressure that Proposition 227 has exerted on English learners through schools and teachers is having a positive influence on academic performance and student welfare within the class. As seen in recent studies (see Ramos, 2005 for a more detailed analysis), English learners were not performing as expected prior to the adoption of this proposition in programs taught only or overwhelmingly in English. It seems that they are getting better results in alternative bilingual programs. It may not come as a surprise, then, that the primary objective in SEI programs is the teaching of communicative English, sounds and illustrations and vocabulary development that have relegated reading and writing (GotoButler, Orr, Bousquet, Gutierrez, \& Hakuta, 2000). 


\section{Conclusions}

Sustained contact with the second language speakers and the social pressures on the educational system have created needs among students that favor the development of positive attitudes towards learning English. However, those attitudes were expected to be much more positive, since the need for an instrumental use of English as means of communication in American society is self-evident. The future prospects of these students, their career choices and social development coexist with the dominance of English as language of communication. It seems that Proposition 227's eradication of native languages as a complementary tool for instruction is not having the desired effect that the proponents of this initiative expected. The excessive emphasis of mastering English in such a short period of time is not helpful, although its utility for social communication is admitted by everyone. Future studies should confirm the existence of what we have called English language use pressure and its effect on the area of student attitudes. Data collected on the percentage of students redesignated since the implementation of Proposition 227 indicate that it remained stable at $8 \%$ seven years later (Grissom, 2004). Results on California standardized tests indicate that such pressure is having a negative effect on the academic progress of Mexican-American students.

\section{IMPLICATIONS AND SUGGESTIONS FOR FUTURE RESEARCH}

The results of this study emphasize the relevance of contact with speakers of the other community when learning a second language. Coercive measures against native languages and the excessive emphasis on the acquisition of English only for communication are undermining the progress of minority language students. Possibly, contributing factors, unrelated to this study, such as the isolation of the Mexican-American community, the de facto segregation in schools and other aspects of social nature, namely, job discrimination, structural racism ... and history. In this context it is necessary to promote unequivocal awareness in government agencies to promote the use of students' first language. Similarly, it is recommendable that procedures be carried out at the school level for parents to become more informed by the districts on the models of instruction available to students. Finally, this study would tend to indicate that when you start a reform from the top without community involvement, the consequences are negative. Further studies are needed to determine the presence of what we have termed English language pressure in Mexican-American students. Research is also needed to understand this construct and to examine any possible relationship with student attitudes and the success with which students learn a second language.

\section{REFERENCES}

Alamillo, L. and Viramontes, C. (2000). "Reflections from the classroom: Teacher perspectives on the implementation of Proposition 227", in Bilingual Research Journal, 25:1\&2: 1-13.

Ball, A. and Lardner, T. (1997). "Dispositions toward language: Teachers constructs of knowledge and the Ann Arbor Black English case", in College Composition and Communication, 48, 4: $469-485$. 
Crawford, J. (2000). At war with diversity: US language policy in an age of anxiety. Bilingual Education and Bilingualism, 25. Tonawanda, NY: Multilingual Matters.

Echevarria, J., Powers, K. and Short, D. (2006). "School Reform and Standards-Based Education: A Model for English-Language Learners", in The Journal of Educational Research, 99, 4: $195-211$.

Eleni, P. (2001). "Moving from ESL classroom into the mainstream: An investigation of English language anxiety in Mexican girls", in Bilingual Research Journal, 25,1\&2: 1-8.

Flores, B. (2001). "Bilingual education teachers' beliefs and their relation to self-reported practices", in Bilingual Research Journal, 25, 1: 275-299.

Francis, D., Lesaux, N. and August, D. (2006). "Language of instruction", in D. August \& T. Shanahan, (eds.), Developing literacy in second-language learners. Mahwah, NJ: Lawrence Erlbaum, 365-413.

García-Nevarez, A. G., Stafford, M. E. and Arias, B. (2005). "Arizona elementary teachers' attitudes toward English language learners and the use of Spanish in classroom instruction", in Bilingual Research Journal, 29, 2: 295-317.

Gardner, R.C. (1985). The role of attitudes and motivation in second language acquisition. Clevendon: Multilingual Matters.

Grissom J. B. (2004). "Reclassification of English Learners", in Education Policy Analysis Archives, 12, 36: 1-38.

Genesse, F., Lindolm-Leary, K., Saunders, W., and Christian, D. (2005). "English Language Learners in U.S. Schools: An Overview of Research", in Journal of Education for Students Placed at Risk, 10,4: 363-385.

Goto-Butler, Y., Orr, J. E., Bousquet Gutierrez, M., and Hakuta, K. (2000). "Inadequate conclusions from an inadequate assessment: What can SAT- 9 scores tell us about the impact of Proposition 227 in California?", in Bilingual Research Journal, 24: 141-154.

Karabenick, S. A., and Clemens Noda, P. A. (2004). "Professional development implications of teachers' beliefs and attitudes toward English language learners", in Bilingual Research Journal, 28, 1: 1-22.

Lee, S. K. (1999). “The linguistic minority parents' perceptions of bilingual education”, in Bilingual Research Journal, 30, 1: 107-122.

Lee, S. K. (2006). “The Latino students' attitudes, perceptions, and views on Bilingual Education”, in Bilingual Research Journal, 23, 2-3: 199-210.

López, M. G., and Tashakkori, A. (2006). "Differential outcomes of two bilingual education programs on English language learners", in Bilingual Research Journal, 30, 1: 123-145.

Madrid, D. (1999). La investigación de los factores motivacionales en el aula de idiomas. Granada: Grupo Editorial Universitario.

Madrid, D. and Pérez Cañado, M. L. (2001). "Exploring the student's motivation in the EFL class", in E. García Sánchez (ed.), Present and Future Trends in TEFL. Universidad de Almería: Secretariado de publicaciones, 321-364.

Martín Moreno, F. (2004). México mutilado. México, D.F.: Alfaguara.

McField, G. (2006). "The many faces of Structured English Immersion", in The International Journal of Foreign Language Teaching, 16-24.

Mora, J. K. (1999, January). "Teachers' beliefs about biliteracy instruction: Commonalities, divergence \& dilemma". Paper presented at the Annual Conference of the National Association for Bilingual Education, Denver, CO.

Mora, J. K. (2001). "Dueling models of dual language instruction: A critical review of the literature and program implementation guide", in Bilingual Research Journal, 25, 4: 417-442. 
Office of English Language Acquisition (2006). California: rate of LEP growth 1994-2005. Descargado el 10 de Enero de 2008, de http://www.ncela.gwu.edu/expert/faq/08leps.html

Ramos, F. (2001). "Teachers' opinions about the theoretical and practical aspects of the use of the native language instruction for language minority students: A cross-sectional study", in Bilingual Research Journal, 25, 3: 251-268.

Ramos, F. (2005). "Spanish teachers' opinions about the use of Spanish in Mainstream English classrooms: before and after their first year in California", in Bilingual Research Journal, 29, 2: 411-433.

Ramos, F. (2007). "What do parents think of two-way bilingual education? An analysis of responses", in Journal of Latinos and Education, 29, 2: 139-150.

Rendón, A. B. (1971). Chicano Manifesto. New York: Macmillan.

Rolstad, K., Mahoney, K., and Glass, G. (2005). "The big picture: A meta-analysis of program effectiveness research on English language learners", in Educational Policy, 19, 4: 572594.

Slavin, R., and Cheung, A. (2005). "A synthesis of research of reading instruction for English language learners", in Review of Educational Research, 75, 2: 247-284.

Sook Lee, J., and Oxelson, E. (2006). "It's not my job: K-12 teacher attitudes toward students' heritage language maintenance", in Bilingual Research Journal, 30, 2: 453-477.

Thomas, W. P., and Collier, V. P. (2004). A national study of school effectiveness for language minority students' long-term academic achievement final report: Project 1.1. Santa Cruz, CA: Center for Research on Education, Diversity, and Excellence.

Valencia, R. R., and San Miguel, G. (1998). "From the treaty of Guadalupe Hidalgo to Hopwood: The plight and struggle of Mexican Americans in the Southwest", in Harvard Educational Review, 68, 3: 353-405.

Unz, R., and Tuchman, G. M. (1997). "English campaign begins", accessed on August 15th, 2007, de http://onenation.org/unz101997.html

Unz, R. and Tuchman, G. M. (1998). Text of Proposition 227, accessed on August 15 $5^{\text {th }}$, 2007, de http://onenation.org/fulltext.html

Uribe, D. (2001). Las actitudes del alumnado hacia la clase de inglés: estudio comparado de dos muestras de hispanohablantes en California y España. Tesis doctoral no publicada: Universidad de Granada.

Uribe, D., Gutiérrez, J. y Madrid, D. (2008). "Las actitudes del alumnado hacia el aprendizaje del inglés como idioma extranjero: estudio de una muestra en el sur de España”, en Porta Linguarum, 10: 85-100. 